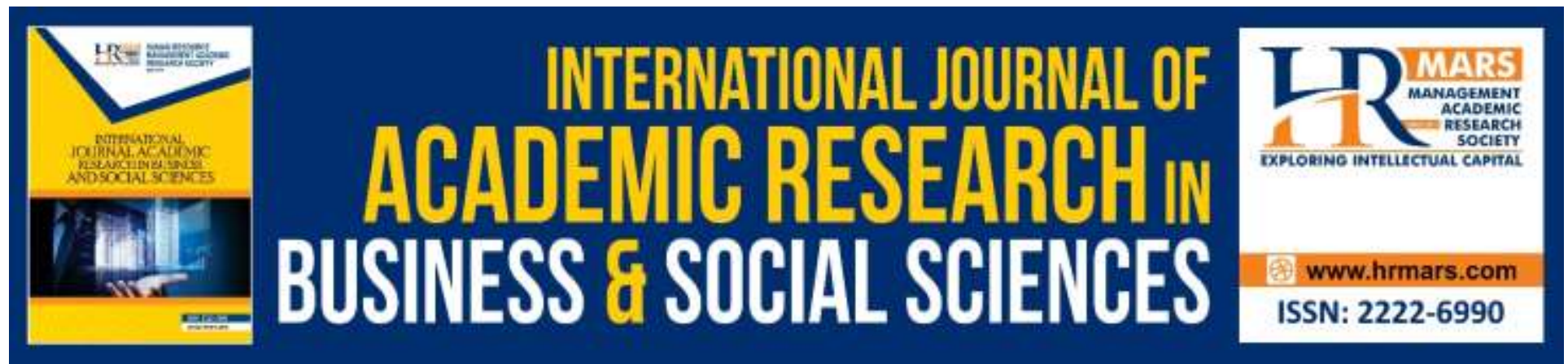

\title{
A Study of Stress Factor towards Oil Palm Workers' Productivity at Felda Techno-plant Gugusan Waha, Kota Tinggi
}

Muhd Faiz Bin Mohamad, Nurulain Binti Isa, Nur Nabila Huda Binti Aziz

To Link this Article: http://dx.doi.org/10.6007/IJARBSS/v9-i11/6637

DOI: 10.6007/IJARBSS/v9-i11/6637

Received: 07 November 2019, Revised: 18 November 2019, Accepted: 29 November 2019

Published Online: 01 December 2019

In-Text Citation: (Mohamad, Isa \& Aziz, 2019)

To Cite this Article: Mohamad, M. F. B., Isa, N. B., \& Aziz, N. N. H. B. (2019). A study of Stress Factor towards Oil Palm Workers' Productivity at Felda Techno-plant Gugusan Waha, Kota Tinggi. International Journal of Academic Research in Business and Social Sciences, 9(11), 1086-1093.

Copyright: (C) 2019 The Author(s)

Published by Human Resource Management Academic Research Society (www.hrmars.com)

This article is published under the Creative Commons Attribution (CC BY 4.0) license. Anyone may reproduce, distribute, translate and create derivative works of this article (for both commercial and non-commercial purposes), subject to full attribution to the original publication and authors. The full terms of this license may be seen at: http://creativecommons.org/licences/by/4.0/legalcode

Vol. 9, No. 11, 2019, Pg. 1086 - 1093

Full Terms \& Conditions of access and use can be found at http://hrmars.com/index.php/pages/detail/publication-ethics 


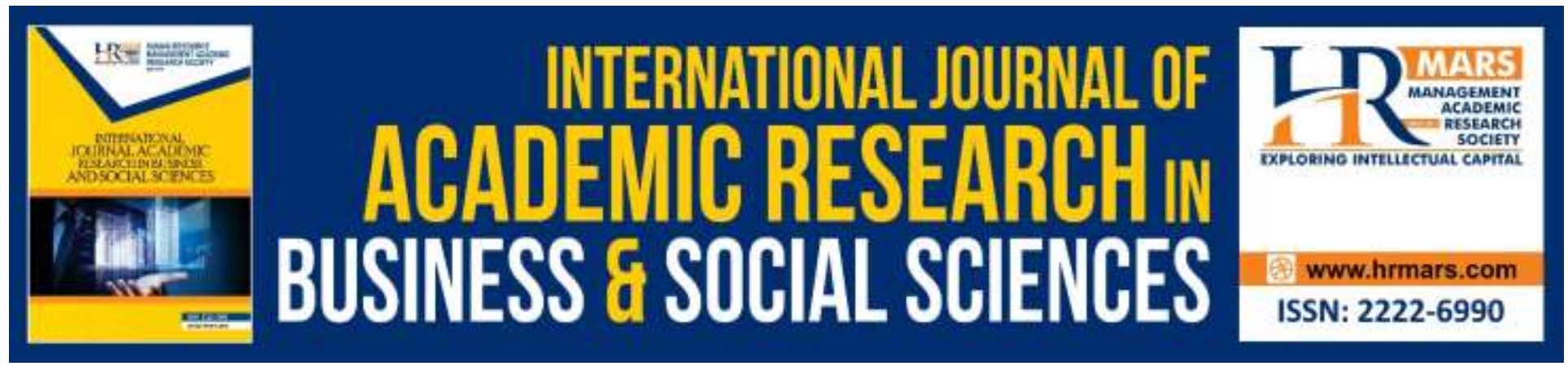

\title{
A Study of Stress Factor towards Oil Palm Workers' Productivity at Felda Techno-plant Gugusan Waha, Kota Tinggi
}

\author{
Muhd Faiz Bin Mohamad, Nurulain Binti Isa, Nur Nabila Huda \\ Binti Aziz \\ Faculty of Plantation and Agrotechnology, UiTM Jasin, Melaka, Malaysia \\ Email: mohamadfaiz507@yahoo.com,nurulainisa@uitm.edu.my, \\ nabila7372@melaka.uitm.edu.my
}

\begin{abstract}
The study was conducted to recognize the relationship of stress with oil palm workers' productivity, which are consist the factor of wages, workload, management style and social influence pressure. Major aim of this study is to determine the relationship between the factors of stress and productivity of oil palm workers, to evaluate the dominant factor of stress that influences the productivity of oil palm workers and to make appropriate recommendations to manage stress problem based on the finding of the study. The study was focused on oil palm harvester that working in Felda Techno-plant In Johor district and 80 respondents were identified to be asked by using a questionnaire and interview section. Data was analyzed by using Statistical Package for Social Science (SPSS). Nevertheless, result show one of the three factors of stress are not correlate which is workloads, where it does not have any relationship with oil palm workers' productivity. The result for most dominant factor is wages of oil palm workers and followed by social influence pressure and management style. Total correlated factors that influence oil palm workers' productivity was 0.195 . It can explain that, independent variable affecting $19.5 \%$ of oil palm workers' productivity.
\end{abstract}

Keywords: Productivity, Stress, Wages, Workload, Management Style

\section{Introduction}

In oil palm plantation, harvester is a part of vital role in increasing the productivity. As a human being, stress can affect the performance of the oil palms workers (Mihac, 1997). Stress is referring to the response of an outcome of individual to the external environment condition such as excessive psychological behaviour and physiological pressure to individual (Ivancevinch, 
Konapske \& Matteson, 2006). Productivity refers to the quantity of output that can be produced by a unit of input where the output is the product or service that was produced by the organization. Yates (1979), mention stress in proper amount is a necessary ingredient in any person whose life is going to clear vitality. In previous studies, many researchers have conducted a study about stress. But lack of study in the plantation sector. If we realize that working in plantation have many challenges that worker needs to face, for (Yates)example, exposure to danger, hazard and possibility to get injured is high. Sometimes, top management needs to push their worker ability to achieve their target to generate higher income. As we know in oil palm plantation, productivity is an important thing that they need to concern in a line to get high profit. Workers might become stress when management puts high expectation and responsibility on their workers' abilities.

Gibsin, Ivancevich and Donnelly (1955) defined stress as an adaptive reaction mediated by personal differences and psychological process, which is can give side effect in action, situation or physical demand in person. Both can be gathered; individual differences and different adaptive capabilities are the factors that would cause stress regularly to differ among individual or workers. Thus, this study aims at determining the factor and effect of stress toward productivity among oil palm workers in the Felda Techno - plant, Gugusan Waha, Kota tinggi.

\section{Materials and Methods \\ Sample Size}

This study was conducted at Felda Gugusan Waha, Kota Tinggi, Johor. The selection of sample size is important to generate high quality results of the data. Researcher has been used stratified sampling to complete data collection section. Stratified sampling is where the huge population that divided into the group. The target respondent is an oil palm harvester. The estimation of sample size was conducted by following Krejcie \& Morgan 1970 table. Total population of oil palm harvester is 109 and the total respondents selected is 80 harvesters.

\section{Questionnaire}

Zikmund, (2003) mention that specific data for the research that was collected by first-hand known as primary data or raw information. Questionnaires application is selected to compile information from the targeted respondents. Structure of the questionnaire is consisting of constituent in the theoretical framework in figure 1. To reduce bias data the measurement of the questionnaire is used Likert's scale. 


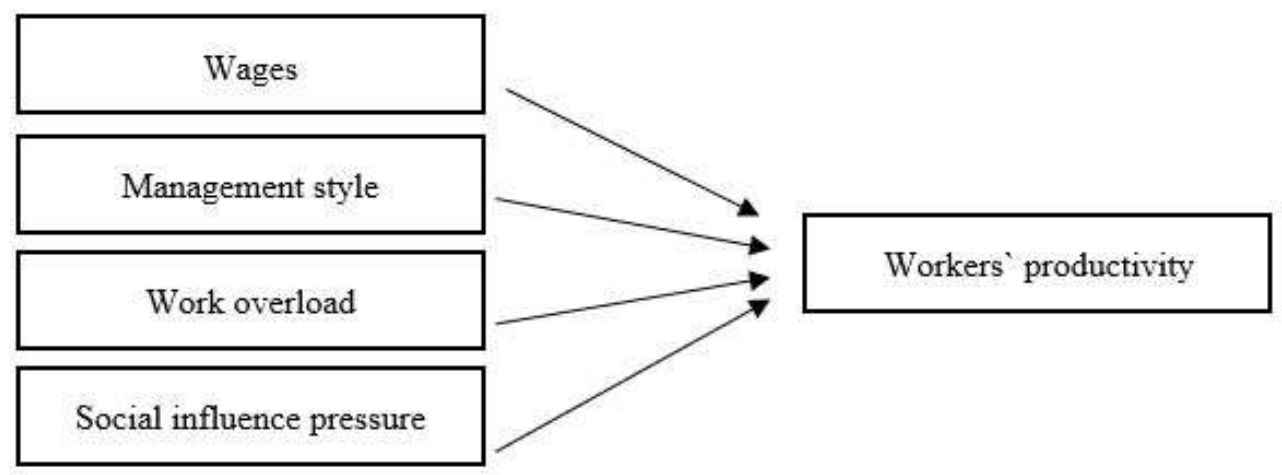

Figure 1. Theoretical Framework

\section{Reliability Analysis}

Pilot test was conducted to test the reliability of the questionnaire. 10 sets of questionnaires have been distributed to the 10 respondents to test the reliability of each question. Cronbach's Alpha must exceed than 0.6. If less than the value, researcher must improve the questionnaire until the value reach 0.6 to be accepted.

\section{Descriptive Analysis}

Descriptive analysis is a translation of data into an easier form to interpret by rescheduling, gathering and manipulating the data into the useful and straight forward information.

\section{Correlation Analysis}

Correlation analysis was conducted to analyse the relationship between two variables that known as dependent variables and independent variables. This model has been considered because this research is using interval scale. The $r$ values range 1.0 which indicate positive relationship and for $r=-1.0$ shows the negative relationship of correlation.

\section{Multiple Linear Regression}

Multiple linear regression is a statistical method that is concerned about the relationship between a dependent variable $(\mathrm{y})$, and one or more independent variable $(\mathrm{x})$. The multiple linear regression function also to evaluate the possible or dominant independent variable that can affect the dependent variable.

\section{Results and Discussion}

Table 1 listed the result of Cronbach's Alpha is 0.848 and it was greater than 0.60. Main purpose of the pilot test is to identify the possible issue in the initial questionnaire. So, the reliability analysis result was acceptable and further study can be proceed using this questionnaire. 
Table 1. Cronbach's Alpha value.

\begin{tabular}{cc}
\hline Cronbach's Alpha & N of items \\
\hline 0.848 & 10 \\
\hline
\end{tabular}

Table 2 state the demographic factor which consists of workers' nationality, ages, educational level, experience, and wages. 95\% from the respondent is from Indonesia and another $5 \%$ is from Bangladesh. Most of harvester have age between 30 to 40 years old and does not go to school. Majority of the harvester have a 5 to 10 years working experience and the rate of wages is around RM 1000.00 to RM 1500.00.

Table 2. Frequency of the demographic factor.

\begin{tabular}{llcc}
\hline Variable & Categories & Frequency & Percentage (\%) \\
\hline Nationality & Indonesia & 76 & 95.0 \\
& Bangladesh & 4 & 5.0 \\
\hline Ages & $20-30$ Years & 23 & 28.8 \\
& $30-40$ Years & 35 & 46.8 \\
& $40-50$ Years & 20 & 25.0 \\
& $50-60$ Years & 2 & 2.5 \\
\hline Educational Level & Does not go to school & 51 & 63.8 \\
& Primary school & 25 & 31.3 \\
& Secondary school & 2 & 2.5 \\
& Diploma & 2 & 2.5 \\
& Degree & 0 & 0 \\
\hline Experience & $1-5$ years & 23 & 28.8 \\
& $5-10$ years & 30 & 37.5 \\
& $10-15$ years & 10 & 15.5 \\
& $15-20$ years & 17 & 21.3 \\
\hline Wages & RM 1000 - RM 1500 & 62 & 77.5 \\
& RM 1500 - RM 2000 & 14 & 17.5 \\
& RM 2000 - RM 2500 & 4 & 5.0 \\
\hline
\end{tabular}

Objective 1 is to determine the relationship between the factors of stress that affects the productivity of oil palm workers. Correlation analysis is conducted to answer objective 1 . From Table 3, it states that wages (0.324) have a moderate positive relationship with productivity. Kabir (2011) supports the result and mention that the wages are significantly affecting the workers' productivity. Second factor that has relationship with workers' productivity is social influence pressure (0.268). It is a weak positive relationship and the statement supported by Clayton et al., (2010) where social influence pressure has a little relationship with the workers' productivity. Next is a management style (0.242) and this relationship is a weak positive with workers' 
productivity. Fairbrother \& Warn (2003); Ejike (2018) agree that management style has significant effect to workers' productivity. Last factor is workload (-0.34) and it shown that there is no relationship with worker's productivity. Similar results were obtained by Manzoor, Awan, \& Marian (2012) where the workers' productivity was not significantly related to workload problem.

Table 3. Result from Pearson correlation analysis.

\begin{tabular}{lll}
\hline Elements & $\begin{array}{l}\text { Significant } \\
(\mathbf{p}-\text { value) }\end{array}$ & $\begin{array}{l}\text { Correlation } \\
(\mathbf{r}-\text { value) }\end{array}$ \\
\hline Wages & 0.003 & 0.324 \\
\hline Social influence pressures & 0.016 & 0.268 \\
\hline Management style & 0.030 & 0.242 \\
\hline Workload & 0.762 & -0.34 \\
\hline
\end{tabular}

Objective 2 is to evaluate the dominant factor of stress that influences the productivity of oil palm workers. Based on research finding, alternative hypothesis accepted where, there is a dominant factor of stress that affects the productivity of oil palm workers in Felda Techno-Plant at Johor. It indicates the possible factor of stress that influences the productivity of oil palm workers by following the standardize coefficient. Wages are the first dominant factor that affects the oil palm workers' productivity. The value of the standardized coefficient from table 4, wages is 0.272 . Where the value is more than other factor like social influence pressure $(0.210)$ and management style (0.197). The similar result from previous study was supported by Vieira \& Serrano (2005) where wages are the most crucial variable that contribute large rate of workers' productivity. So, the result from this study was accepted and consider wages are the dominant factor that influences the workers' productivity.

Table 4. Multiple linear regression result.

\begin{tabular}{|c|c|c|c|c|c|c|}
\hline Model & & $\begin{array}{l}\text { Unstandardized } \\
\text { Coefficients }\end{array}$ & & $\begin{array}{l}\text { Standardized } \\
\text { Coefficients }\end{array}$ & $t$ & Sig. \\
\hline \multirow[t]{5}{*}{ Variables } & & B & $\begin{array}{l}\text { Std. } \\
\text { Error }\end{array}$ & Beta & & \\
\hline & (Constant) & 0.555 & 1.041 & & 0.533 & 0.596 \\
\hline & Mean_Wages (X1) & 0.373 & 0.144 & 0.272 & 2.585 & 0.012 \\
\hline & $\begin{array}{l}\text { Mean_Management } \\
\text { (X3) }\end{array}$ & 0.306 & 0.164 & 0.197 & 1.867 & 0.066 \\
\hline & Mean_Social (X2) & 0.281 & 0.142 & 0.210 & 1.983 & 0.051 \\
\hline
\end{tabular}

Objective 3 is to make appropriate recommendation on how stress can be managed based on the finding of the study. In order to encounter stress, there are two kinds of strategies, the first 
one works at the individual level, such as sport activities, effective rest, good time management, role management (Styhre \& Ingelgard, 2003; Ali \& Warfa, 2018). Others are holding up the group by including friends and family members with whom a person may expend the time (Moorhead \& Griffin, 1995, p. 266 -268). Mohsenzadeh (2007) also presents two other strategies to encounter the stress by relaxation: it is a way to help us trim down and removing stress and anxiety through decreasing unnecessary muscular contractions. This is a self-control method that helps to experience less stress in stressful situations.

The dominant factor that influence the workers' productivity is wages. To raise the wages is impossible because most of the companies follow wages rate from Malaysian associated producer agriculture (MAPA), but the management should explain clearly how they pay out the wage to the workers. For example, manager explains to their workers to produce more output to gain higher wages, this is because like oil palm harvester they paid by following their output. According to the Malaysian budget for the years 2019 the minimum wages for that year is RM 1100.00 where the increasing RM50.00 from the years 2018.

\section{Conclusion}

In conclusion, the research was successfully determine the relationship between the factors of stress with oil palm workers' productivity, evaluate the dominant factor that influences the oil palms workers' productivity and suggests the appropriate way to overcome and reduce the problem. All objectives were achieved, three of independent variables which are workers' wages, social influence pressure and management style have a positive relationship with the oil palm workers' productivity. The workload has no relationship with the workers' productivity. Meanwhile, the most dominant factor that influencing the oil palm workers' productivity is wage. Result from this study have supported by researcher of previous studies. The statement that mentioned by Yates (1979) where everyone can experience stress is totally true, but the factors of stress can be different based on the work specification

This study can help organization to figure out the major factor of stress that can lead to the lower workers' productivity. Organization can take appropriate action to control and reduce the problem of stress that can influence productivity among workers. In addition, organization also can apply the recommendation that had suggested from the research finding to reduce the problem. Besides that, it can help government to analyse the factors of stress that influence the workers' productivity that can lead to the stability of the economy. They also can generate effective way to reduce the stress problem among oil palm workers. For the example, government provides some budget for consultation program like motivation event or seminar that related to the main problem. At the end of the day, government can improve the oil palm productivity and maintain the oil palm sustainability.

To be concluded, it stated that worker's wages, social influence pressure and management style has a significant relationship with the oil palm worker's productivity, while, workload has no 
significant relationship with productivity of oil palm worker. The study also showed that, most dominant factor that influenced productivity of oil palm worker is wage.

\section{References}

Ali, M. M., \& Warfa, A. O. (2018). Pupils, Parents and Teachers Perceptions on Causes of Low Achievements in Kenya Certificate of Primary Education Examination: A Case Study in a Public School in Mandera County, Kenya. International Journal of Academic Research in Progressive Education and Development, 7(2).

Clayton, B. M., Staden, V. C. J., \& Lynch, B. (2010). The impact of social influance pressure on professional accountants' ethical reasoning. Paper Presented at the 6th Asia Pacific Interdisciplinary Research in Accounting Conference (APIRA 2010). Sydney, Australia.

Ejike, S. I. (2018). An Assessment of Non-Executive Directors Influence on the Operating Profits of Manufacturing Firms in Nigeria, International Journal of Academic Research in Accounting, Finance and Management Sciences 8 (2): 1-8.

Fairbrother, K., Warn, J. (2003) Workplace dimensions, stress and job satisfaction", Journal of Managerial Psychology, Vol. 18 Issue: 1, pp.8-21,

Ferreira, A., \& Plessis, D. T. (2009). Effect of online social networking on employee productivity. South African Journal of Information Management, 11(1), 1-11.

Ivancevich, J. M., Konopaske, R., \& Matteson, M. T. (2011). Organizational behavior and management (9th ed.). New York, NY: McGraw-Hill.

Kabir, M. M. (2011). Factors Affecting Employee Job Satisfaction of Pharmaceutical Sector. Australian Journal of Business and Management Research, Vol.1 No.9 113-123.

Krejcie, R. V., \& Morgan, D. W. (1970). Determining Sample Size for Research Activities. Educational and Psychological Measurement. 30, 607-610.

Manzoor, A., Awan, H., \& Mariam, S. (2012). Investigating the impact of work stress on job performance: A study on textile sector of faisalabad. Asian Journal of Business and Management Sciences, 2 (1), 20-28.

Serrano, D., \& Vieira, C. (2005). Low Pay, Higher Pay and Job Satisfaction within the European Union: Empirical Evidence from Fourteen Countries. IZA Discussion Paper No. 1558.

Yates, J. E. (1979). Managing stress. New York: Amacom.

Zikmund, W. G., Babin, B. J., Carr, J. C., \& Griffin, M. (2009). Business research methods (8th ed.). USA: South-Western College Publishing.

\section{Acknowledgement}

The authors would like to acknowledge the supervisor, UiTM degree coordinator, lecturers, other researchers and Felda Techno-plant Gugusan Waha, Kota Tinggi.

\section{Corresponding Author}

Nurulain binti Isa, Corresponding author, Plantation Management Department, Faculty of Plantation and Agrotechnology, UiTM Jasin, Melaka, Malaysia

Email: nurulainisa@uitm.edu.my 